\title{
Centrum i peryferie w „oddolnych” narracjach wojennych z przedmieść Warszawy
}

\section{Abstrakt}

Przedmiotem tego artykułu są relacje między centrum a peryferiami w narracjach wojennych z regionu podwarszawskiego. Analizowane narracje należą do twórczości „oddolnej” (obejmują pamiętniki, wspomnienia, monografie pisane przez historyków amatorów, książki wydawane przez małe, lokalne wydawnictwa, strony internetowe lokalnych instytucji oraz narracje wizualne obecne w przestrzeni miast). Główne poruszane kwestie to: czy relacje między centrum a przedmieściami są opisywane w kategoriach binarnych opozycji, czy raczej na zasadzie stopniowania? Czy „peryferyjni” narratorzy używają strategii mimikry wobec centrum, czy też raczej buntują się przeciw niemu? Artykuł omawia także trzy metaforyczne obrazy pojawiające się w podmiejskich narracjach i wyrażające postawę wobec centrum: obraz Warszawy jako wulkanu, jako pustego środka okręgu i jako góry lub wieży rzucającej cień na okolicę.

Słowa kluczowe: Warszawa, powstanie warszawskie, przedmieścia, metafora.

W pierwszych dniach września 1939 roku warszawskie gazety informowały o specjalnych pociągach „dla pragnących opuścić stolicę” (Specjalne pociagi 1939: 6). Ewakuacja nie była przymusowa ani nawet zalecana, niemniej jednak uruchomiono dodatkowe pociągi podmiejskie do Otwocka, Piaseczna, Grójca, Grodziska i Milanówka oraz innych okolicznych miejscowości. „Osiedla o małym nasileniu ludności, a więc na prowincji, niewątpliwie nie będą zagrożone nalotami” - zapewniał "Goniec Warszawski”. Już trzy dni później ta sama gazeta donosiła o bombach, które spadły na Otwock, Celestynów, Międzylesie, Pruszków i Grodzisk Mazowiecki i o pierwszych ofiarach śmiertelnych w tych miejscowościach. Fakt, że „[n]aloty nieprzyjacielskie odbywają się również na okolice podmiejskie, zamieszkałe przez letników, oraz kobiety i dzieci wysłane z Warszawy" (Niemieccy bandyci 1939: 5), jest przedstawiany jako dowód na szczególne barbarzyństwo i nieposzanowanie reguł cywilizowanej wojny. „Kurier Warszawski” z 5 września (nr 245, wydanie poranne) na pierwszej stronie zamieścił zdjęcia zbombardowanych ulic w Grodzisku Mazo- 
wieckim i zburzonego przez bomby sanatorium w Otwocku; na dalszych stronach numeru pojawiają się określenia takie, jak „bandyckie metody” czy „bandyckie bombardowanie i nikczemne dywersje".

Już w pierwszych dniach wojny zatem centrum (stolica) było w pewnym sensie przeciwstawiane peryferiom (okolicom podmiejskim). Od mieszkańców miasta oczekiwano heroicznej walki, wkrótce też codzienne gazety zapełniły się relacjami o ich bohaterskich czynach. Obraz mieszkańców przedmieść był bardziej niejednoznaczny. Często przedstawiano ich jako ofiary wojny - i to, w przeciwieństwie do mieszkańców stolicy, jako ofiary zastraszone i bezradne. W drugiej połowie września pojawiają się relacje o mieszkańcach przedmieść dostarczających do głodującej stolicy jedzenie, nawet tu jednak nie są oni przedstawiani jako bohaterowie jednoznacznie pozytywni. „Express Poranny” z 20 września (Skarby wojenne 1939) pisał o „naszych podstołecznych wieśniakach”, którzy przywożą do Warszawy kapustę, marchewkę i ziemniaki i sprzedają je po astronomicznych cenach. Inny artykuł na tej samej stronie sugeruje, że sprzedawcy ci nie są rolnikami, którzy sami uprawiali warzywa, tylko sprytnymi mieszkańcami podwarszawskich miejscowości, którzy korzystając z zamieszania, ukradli plony z pól i ogródków.

Wojenny obraz mieszkańców przedmieść jest zatem ambiwalentny i pełen niejasności. Warszawskie gazety pisały często o tym, czego oczekuje się od mieszkańców stolicy, nie było natomiast oczywiste, jaka powinna być postawa mieszkańców przedmieść. Czy powinni spieszyć na pomoc w obronie stolicy, czy też raczej szykować w swoich podmiejskich domach miejsca dla ewakuowanych? Czy ich rolą jest zapewnianie zaplecza walczącym, czy też sami powinni włączać się do walki? Wreszcie - czy tak samo postrzegali swoją rolę sami mieszkańcy przedmieść jak ich warszawscy sąsiedzi?

Celem tego artykułu jest przedstawienie wojennych narracji z przemieść Warszawy z perspektywy nie historyka czy literaturoznawcy, lecz z zastosowaniem metody krytycznej analizy dyskursu. Jeśli mówimy o wojnie w okolicach Warszawy, z czyjej perspektywy ją oglądamy? Mieszkańca Śródmieścia, Pragi, Włoch czy może Brwinowa lub Grodziska? Zdarzenia lat 1939-1945 wyglądały przecież inaczej w każdym z tych miejsc. Czyj punkt widzenia jest więc najlepiej znany, przyjmowany za „obowiązujący”? Co jest oceniane jako bardziej lub mniej wartościowe, bohaterskie, słuszne? Jak wyglądała wojenna Warszawa w oczach prowincji, ale prowincji bardzo nieodległej, oddalonej o mniej niż godzinę jazdy koleją?

\section{Mikroregion: „Mały Londyn”}

Relacje między centrum a peryferiami, również w kontekście wojny, były już nieraz przedmiotem refleksji naukowej. Na ogół jednak analizy te były prowadzone w skali makro (Rybicka 2015: 13): świata, Europy, makroregionu lub państwa. Analizowanymi regionami, sytuowanymi często w opozycji do centrum, były więc na ogół 
Śląsk, Kaszuby lub też większe obszary, jak na przykład Ziemie Odzyskane czy Kresy. Ponadto analiza, czy to w makro-, czy też mikroskali, dotyczyła prawie zawsze tekstów funkcjonujących w obiegu ogólnym. W skali makro przedmiotem refleksji jest na przykład sytuacja „peryferyjnych literatur narodowych lub makroregionalnych (na przykład środkowoeuropejskich) w perspektywie literatury światowej" (Rybicka 2015: 13). W skali mikro wskazuje się na regionalizm w twórczości uznanych pisarzy (na przykład Szczepana Twardocha, Andrzeja Stasiuka, Olgi Tokarczuk) lub też twórców zaliczanych do literatury popularnej (na przykład Katarzyna Grochola), w każdym razie jednak funkcjonujących w ogólnym, „narodowym” obiegu.

Przedmiotem analizy w tym artykule są natomiast teksty funkcjonujące $\mathrm{w}$ innym obiegu oraz relacje między centrum a peryferiami rozpatrywane w mniejszej skali i dotyczące bardzo specyficznego obszaru. Podmiejskie okolice na zachód Warszawy, a więc miejscowości takie, jak Pruszków, Brwinów, Milanówek, Podkowa Leśna i Grodzisk Mazowiecki, nigdy nie tworzyły formalnie wyodrębnionej jednostki administracyjnej. Od czasów przedwojennych obszar ten istniał jednak jako pewna całość. Jest to dobrze widoczne w literaturze pamiętnikarskiej (dzieci z jednej miejscowości chodzą do szkoły w drugiej, mieszkańcy jeżdżą do sąsiednich miejscowości na zakupy). Artykuł z roku 1961 dotyczący walki z „,reakcyjnym podziemiem” określa tę okolicę mianem "Małego Londynu” (Halaba 1961: 14) i określenie to, pomyślane jako obelga, zostało z dumą przyjęte przez lokalnych mieszkańców. Elementem scalającym ten obszar i łączącym go z Warszawą są linie kolejowe: warszawsko-wiedeńska oraz kolejki EKD (obecnie WKD). Mikroregion ten obejmował obszary o odmiennym charakterze i historii: obok tradycyjnego, istniejącego od wieków miasteczka (Grodzisk) znajdował się w nim ośrodek przemysłowy (Pruszków) oraz powstałe w okresie międzywojennym osiedla willowe (Milanówek, Podkowa Leśna), a także okoliczne wsie i majątki ziemskie.

Relacje między centrum a peryferiami w tym mikroregionie zawsze były dość skomplikowane. $Z$ jednej strony miejscowości te zawsze zaznaczały swoją odrębność od Warszawy, często budując własną tożsamość na zasadzie kontrastu. Milanówek czy Podkowa Leśna przed wojną stawały się miejscem ucieczki z zakurzonej, hałaśliwej Warszawy (por. Szurek 2016). Nie bez znaczenia było też, że mieszkańcy tych miejscowości często podjęli świadomą decyzję niemieszkania w Warszawie. Tożsamość mieszkańców okolic podmiejskich była więc często tożsamością z wyboru, przeciwstawianą tożsamości warszawskiej (w kontekście współczesnym zwrócił na to uwagę Wojciech Chmielarz, por. Chmielarz 2017). Ale też miejscowości te zawsze były z Warszawą mocno związane, przede wszystkim dzięki bardzo dobremu skomunikowaniu ze stolicą. Również w wojennych wspomnieniach mieszkańców wyjazdy do Warszawy nie są „wyprawami do miasta”, lecz codzienną praktyką związaną z dojeżdżaniem do pracy lub szkoły. Anna Hładowska w pamiętniku z lat 1939-1945 notuje na przykład pod datą 20 kwietnia 1941 roku (autorka miała wówczas 14 lat): „Niedziela, wczoraj jeździłam do Warszawy, woziłam tam chleb i kaszę, zarobiłam na czysto 12 zł" (Hładowska 2014: 327). Pod datą 1 maja 
tego roku pojawia się zapis: „Jeżdżę do Warszawy systematycznie, wożąc chleb i kaszę” (Hładowska 2014: 327). W sierpniu sytuacja się zmienia: „Teraz w Warszawie wszystko taniej, więc przywożę z Hali Koszykowej słoninę i chleb” (Hładowska 2014: 329). We wrześniu autorka zaczyna się uczyć w Szkole Handlowej, co oznacza codzienne dojazdy do Warszawy. Warszawa nie jest więc z pewnością odległą „stolicą", odwiedzaną tylko przy szczególnych okazjach, lecz miejscem znanym, codziennym. W wielu wspomnieniach wojennych mamy do czynienia z czymś na kształt podwójnej perspektywy: Warszawa może być jednocześnie bardzo blisko - kiedy jedzie się tam do szkoły, odwiedzić rodzinę czy zrobić zakupy - i bardzo daleko, kiedy obserwuje się łuny pożarów lub słyszy odgłosy dalekich eksplozji, stojąc we własnym spokojnym, podmiejskim ogrodzie.

\section{Literatura „oddolna”}

Wojnę na zachodnich przedmieściach Warszawy lub też jej epizody opisywali różni znani pisarze i historycy, w tym na przykład Jarosław Iwaszkiewicz (Pod Akacjami, Kościół w Skaryszewie), o podwarszawskich okolicach wspominają Michał Głowiński (Magdalenka z razowego chleba) czy Marek Edelman (Prosto się mówi jak się wie). Przedmiotem mojej analizy będą jednak teksty, które nie należą do ogólnego obiegu literatury - a więc relacje, wspomnienia i historie spisywane przez amatorów, publikowane najczęściej w niewielkich nakładach przez małe, lokalne wydawnictwa. Tego rodzaju książki zazwyczaj nie są sprzedawane w księgarniach można je kupić na lokalnych imprezach kulturalnych, czasami w centrach kultury, kioskach parafialnych lub bibliotekach. Chociaż czasami dzieła te starają się przedstawiać wydarzenia lokalne w perspektywie narodowej czy nawet globalnej, wyraźnie są adresowane do lokalnych społeczności.

Tego rodzaju „oddolna” literatura może obejmować bardzo różne gatunki. Relacje wojenne odnajdujemy więc w pamiętnikach, zarówno tych spisywanych na bieżąco, jak i we wspomnieniach utrwalanych dopiero po latach. Zdarzają się również - chociaż rzadziej - wspomnienia fabularyzowane lub powieści oparte na faktach autobiograficznych. Monografie historyczne pióra lokalnych badaczy również mogą zawierać fragmenty wspomnień oraz wstawki beletrystyczne lub eseistyczne. W społecznościach lokalnych wojenne wspomnienia były też oczywiście często przekazywane w formie ustnej. Niektóre z takich relacji zostały zarchiwizowane - spisane przez lokalnych badaczy lub też nagrane bądź sfilmowane. Istnieją również narracje wizualne, na przykład rozmieszczone w przestrzeni miast tablice pamiątkowe, oraz narracje w przestrzeni cyfrowej (często mamy tu do czynienia z hybrydyczną przestrzenią jednocześnie cyfrową i realną; przykładem może być strona Miejsca Pamięci! Walka i Konspiracja!). Literatura lokalna obejmuje zatem wiele bardzo rozmaitych form, często trudnych do jednoznacznego sklasyfikowania gatunkowego. Bardzo różna jest w tych utworach również perspektywa narracyjna 
oraz zakres relacjonowanych zdarzeń; różny wreszcie jest też czas powstania analizowanych przeze mnie utworów. Wśród omawianych przykładów znajdują się pamiętniki spisywane podczas wojny, opublikowane jednak dopiero w ostatnich latach (Woźnicka 2013; Hładowska 2014), wspomnienia spisywane przez uczestników zdarzeń z perspektywy lat (Zalewski; Jakubowski 2014), opracowania pióra uczestników zdarzeń, starające się jednak ukazywać zdarzenia lokalne nie w perspektywie osobistej, na sposób pamiętnikarski, lecz bardziej historiograficznej (Krzyczkowski 1986; Cabanowski 1996; Gmurski 2007; Rumianek 2008; częściowo Wysocki et al. 2004), a także narracje współczesne, tworzone przez osoby, dla których wojna jest doświadczeniem ze wspomnień rodziców lub dziadków. W analizowanych tekstach różna także jest proporcja między perspektywą lokalną a narodową czy globalną. Niektórzy autorzy starają się przede wszystkim umieścić zdarzenia lokalne w szerszym kontekście (zwłaszcza Gmurski, częściowo Krzyczkowski), inni świadomie zawężają pole widzenia, koncentrując się tylko na najbliższej okolicy (Wiśniewska 2010; Rumianek 2008). Autorzy pamiętników spisywanych na bieżąco często zdają się wahać, co powinni relacjonować: bliższe im wydarzenia lokalne czy też historię narodową lub globalną, która wydaje im się ważniejsza. W niektórych relacjach - zwłaszcza tych spisywanych przez bardzo młodych pamiętnikarzy - mamy do czynienia z ciekawym przemieszaniem lokalnej i globalnej perspektywy: „Wtorek, 15 października 1935 [...]. Po pierwsze to wojna Włoch z Abisynią, a po drugie to poświęcenie i otwarcie sali gimnastycznej przy naszej szkole" (Woźnicka 2013: 19).

\section{Centrum i peryferie — opozycja i mimikra}

Opisując relacje między centrum a peryferiami, możemy, „sugerować względną rozdzielność obu kategorii, równie dobrze jak postrzegać [je] jako punkty skrajne na określonej skali wartości" (Duszak 2012: 10). W narracjach wojennych z zachodnich przedmieść Warszawy odnajdziemy przykłady obu tych modeli.

Przedmieścia bywają opisywane jako miejsce całkowicie różne od centrum, czasami wręcz jako antyteza Warszawy. Jest to widoczne zwłaszcza we wspomnieniach dotyczących okresu tuż po upadku powstania warszawskiego. Pielęgniarka ze Szpitala Wolskiego, która po upadku powstania opuściła Warszawę wraz z transportem rannych, wspomina trudną drogę nocą, po błotnistej szosie, z przeładowanym wozem pełnym cierpiących ludzi. Po długiej podróży transport dociera do Pruszkowa i tam wykończeni, pokryci krwią i błotem warszawiacy widzą wychodzących z kościoła, odświętnie ubranych ludzi (Rumianek 2008: 12). Witold Zalewski, mieszkaniec Grodziska, który całe powstanie przeżył w Warszawie, ukrywając się w piwnicy domu na Lesznie, i potem trafił do pociągu zmierzającego do obozu w Pruszkowie, w ten sposób opisuje wyjazd z Warszawy: „Pociąg tymczasem rusza. Mija kilka minut i otwiera się przed nami widok zaskakujący, szokujący. Mijamy Włochy i przez okno widzimy ludzi, masę ludzi, którzy chodzą po ulicy, czymś handlują, rozma- 
wiają. Jak to jest? Myśmy myśleli, że to, co się dzieje w Warszawie, dzieje się w całej Polsce, a jeśli nie w całej, to w pobliżu Warszawy. Kilka kilometrów stąd piekło, a tu niebo" (Zalewski: 78). W pewien sposób koresponduje to z rozumieniem regionalności, o którym pisze Małgorzata Mikołajczak, odwołując się do poglądów Stephanie Foote i Roberta Marii Dainotto: pisarstwo regionalne ma charakteryzować się budowaniem opozycji takich jak natura-kultura, rustykalne-industrialne itp. (Mikołajczak 2015: 31). W wielu narracjach wojennych mamy do czynienia z podobnymi parami przeciwieństw: niebezpieczna Warszawa i bezpieczne przedmieścia, ciemność (zasnuta dymami stolica) i światło (słoneczny podmiejski ogród), chaos (walki uliczne w Warszawie) i porządek (spokojne podmiejskie drogi).

Obraz wojny na przedmieściach jest jednak bardziej złożony i nie można go w całości wpisać w te proste kontrasty. Wiele lokalnych narracji stosuje bowiem drugą z opisanych przez Mikołajczak (2015: 32) strategii: mimikrę. Stawiają one sobie za cel, chociaż nie formułują tego otwarcie, udowodnienie, że to samo, co zaszło w Warszawie, działo się również na przedmieściach, tyle że w mniejszym zakresie czy mniejszej skali. Opracowanie Włochy w cieniu walczacej Warszawy (2008) stara się na przykład polemizować z wizerunkiem Włoch jako idyllicznego obszaru, niedotkniętego klęską powstania. Autorzy podkreślają w nim, że mieszkańcy Włoch brali udział w walkach w wielu punktach stolicy i że również w podmiejskiej okolicy toczyły się walki i przeprowadzano akcje zbrojne. Lokalni historycy często starają się pokazywać, że w małych miejscowościach także działała konspiracja, było tajne nauczanie, działały struktury Państwa Podziemnego. Zaznaczają, że mieszkańców podmiejskich miejscowości również dotykały represje. W monografii poświęconej wsi Kuklówka wymienione są nazwiska siedmiu mieszkańców wsi, którzy należeli do AK, dwóch, którzy zostali wywiezieni na roboty do Niemiec, i dwóch, którzy trafili do obozu zagłady (Gmurski 2007: 132-135). Te działania, które miały istotne znaczenie dla lokalnych społeczności, ale nie wpisują się w strategię mimikry, często zostają zapomniane. Autor Dziejów Kuklówki pisze o „wielkiej humanitarnej akcji” pomagania ludziom szczególnie dotkniętym przez trudne wojenne warunki (dożywianie, rozdawnictwo odzieży i obuwia, zasiłki pieniężne), stwierdza jednak, że organizatorzy tych akcji „[z]ostali już dawno zapomniani, nikt zapewne nie odsłonił im tablicy" (Gmurski 2007: 125). Autorzy podwarszawskich wojennych narracji często podkreślają skromność i małość własnych działań i przeżyć wobec tego, co działo się w stolicy. W takich przypadkach mamy więc do czynienia $\mathrm{z}$ rozumieniem relacji między centrum a peryferiami raczej w kategorii skali niż binarnych opozycji. Widoczny jest tu proces upodabniania się - czy też chęci upodabniania - peryferii do centrum (por. Duszak 2012: 10).

W podwarszawskich narracjach wojennych nie znajdziemy przykładów rebelii przeciw centrum (por. Mikołajczak 2015) - byłoby to oczywiście nie do pomyślenia w ówczesnym kontekście historycznym, zwłaszcza w opowieściach tworzonych po upadku powstania warszawskiego. Niekiedy jednak w narracjach mieszkańców mamy do czynienia z sytuacją, w której peryferie przejmują funkcję centrum - i pła- 
cą za to cenę. W dniu 16 stycznia 1945 roku lotnictwo radzieckie zbombardowało Grodzisk Mazowiecki (w którym nie było już wojsk niemieckich), zabijając wielu ludzi na przepełnionym rynku. Nigdy nie zostało ostatecznie wyjaśnione, czy bombardowanie to było rezultatem pomyłki, czy też świadomym aktem terroru (por. Szurek 2015). W relacji jednego z mieszkańców i świadków nalotu celem ataku była tak naprawdę stolica i centralne instytucje, tyle że instytucje te znajdowały się teraz na przedmieściach: „Ja jednak sądzę, że był to akt terroru nakierowany przeciwko mającym po powstaniu swoją siedzibę w Milanówku i Grodzisku władzom podziemnej Polski - wszak tutaj i w okolicy była kwatera Komendy Głównej AK i Delegatury Rządu” (relacja Kazimierza Skoblewskiego, cyt. za: Cabanowski 1996: 203).

Zdecydowanie najpopularniejsza jest jednak w podmiejskich narracjach strategia mimikry. Lokalne opowieści o wojnie są układane na wzór narracji funkcjonujących w obiegu narodowym, nawet jeśli model ten nie do końca pasuje do miejscowej specyfiki. Eksponowane są przede wszystkim akcje militarne, mimo że zachodni obszar podwarszawski wypełniał inne liczne zadania: przechowywano, naprawiano i wytwarzano bron i amunicję (na przykład w Zakładach Chemicznych „Grodzisk” i w fabryce Sztancmet), przyjmowano zrzuty sprzętu i ludzi, produkowano żywność i środki czystości (na przykład produkcja herbaty Herbid i mydeł w Pruszkowie, wytworów z jedwabiu przeznaczonych na czarny rynek w Centralnej Doświadczalnej Stacji Jedwabniczej w Milanówku). W „narodowych” narracjach rzadko jednak znajdziemy opis walki innej niż z bronią w ręku. Miejscowi historycy często więc "nie wiedzą”, w jaki sposób opowiedzieć o lokalnych wojennych zdarzeniach, takich jak na przykład konspiracyjna działalność gospodarcza.

Obie te przyczyny - chęć upodobnienia się do centrum oraz brak modeli narracji - odpowiadają zapewne za to, że nawet w przestrzeni miejskiej zdarzenia z lokalnej historii są często przedstawiane jako mniej istotne niż te dotyczące historii narodowej. Przykładem może być historia miejsca pamięci w Grodzisku Mazowieckim. Przy głównym placu miasta, na miejscu pozostałym po spaleniu żydowskiego domu, w roku 1943 rozstrzelano dwudziestu przywiezionych z Warszawy więźniów. Następnego dnia po egzekucji ludzie zaczęli składać na tym miejscu kwiaty i palić znicze; później ustawiono również krzyż. W roku 1945 to właśnie w okolicy tego miejsca zginęło najwięcej osób w wyniku radzieckiego nalotu. W roku 1966 wybudowano tam pomnik, który nie upamiętniał jednak ani żydowskiej rodziny, ani (z oczywistych powodów cenzury politycznej) ofiar radzieckiego bombardowania, wymieniał natomiast miejsca bitew stoczonych przez polską i radziecką armię (na przykład Westerplatte, Lenino, Berlin), które z lokalną historią nie miały nic wspólnego. W roku 1989 w miejscu pamięci złożono urnę z ziemią z Katynia, a w roku 1992 dodano tablicę ku czci ofiar nalotu oraz drugą, dotyczącą Armii Krajowej. W roku 2015 miejsce pamięci przebudowano, stawiając nową, potrójną tablicę, poświęconą - oprócz poprzednich wymienionych osób - również żołnierzom wyklętym. Z boku natomiast znajduje się tablica $\mathrm{z}$ nazwiskami rozstrzelanych więźniów z Warszawy. Miejsce ważne dla historii lokalnej zostało więc prawie całkowicie 
podporządkowane historii ogólnej, narodowej. Spośród licznych inskrypcji tylko jedna dotyczy zdarzenia, które miało miejsce w Grodzisku i ludzi, którzy w tym mieście żyli i zginęli. Przegląd tablic pamiątkowych na terenie Włoch pokazuje z kolei, że przeważają tam tablice poświęcone aresztowaniom (czy to przez Niemców, czy później przez NKWD) oraz szpitalom działającym po powstaniu warszawskim. Widać więc wyraźną dominację historii „militarnej” i eksponowanie zdarzeń co prawda lokalnych, ale takich, które można uznać za ważne z perspektywy centrum. Z tego schematu wyłamują się w pewnym stopniu zaledwie jedna lub dwie tablice - poświęcona lokalnym sportowcom oraz strażakom (Gawkowski 2012: 10-14). Schemat podporządkowywania - nawet w kontekście lokalnym - miejscowej historii narracjom państwowym oraz eksponowanie zdarzeń o charakterze militarnym zdają się przełamywać dopiero narracje cyfrowe. Interaktywna mapa na stronie Miejsca Pamięci w Grodzisku Mazowieckim koncentruje się wyłącznie na zdarzeniach lokalnych i zwraca uwagę na historię gospodarczą. Podobnie trasa Okupacyjny Pruszków oprócz miejsc egzekucji oraz akcji zbrojnych zawiera punkty opisujące niewielkie sklepy i zakłady, w których naprawiano i produkowano skarpety, wytwarzano swetry, marmoladę, herbatę czy bimber.

\section{Metafory}

Rejon podwarszawski, zwłaszcza zachodni, od strony wojskowej odegrał małą rolę w powstaniu warszawskim, natomiast przez cały czas jego trwania i miesiące po jego upadku mieszkańcy przedmieść przyjmowali wygnańców z Warszawy, udzielali pomocy ludności zgromadzonej w obozach przejściowych (w tym w głównym Dulag121 w Pruszkowie), organizowali szpitale; prowadzono też akcję ratowania dóbr kultury. Żołnierze AK z okolic podmiejskich znaleźli się w trudnej sytuacji: w pierwszych dniach powstania przeważnie nie mogli włączyć się w walkę ani wykonać powierzonych zadań i często odsyłano ich do domów, potem zaś wezwano ich do spieszenia na ratunek stolicy ${ }^{1}$. W tych dramatycznych okolicznościach ujawniały się napięcia między centrum a przedmieściami, a rozterki i wątpliwości uczestników zdarzeń znajdowały wyraz w metaforycznych obrazach.

Krytyka metaforyczna często jest używana jako narzędzie analizy różnych przekazów związanych z wojną, przede wszystkim ze względu na propagandową siłę oddziaływania metaforycznych obrazów (Foss 2009: 281). W retoryce wojennej metafory często mają wpłynąć na sposób, w jaki w odbiorze publicznym postrzegany jest nieprzyjaciel — na przykład aby pokazać, że wojna jest jedynym możliwym

${ }^{1}$ Rozkaz wyznaczający godzinę „W” dotarł do Pruszkowa (czyli do komendanta Rejonu VI AK o kryptonimie „Helenów”) dopiero o godzinie 15. Rozpoczęcie powstania w rejonie przesunięto więc na godzinę 21; później wiele zaplanowanych akcji anulowano, a licznym żołnierzom rozkazano wracać do domów już w pierwszych dniach sierpnia. Z kolei 14 sierpnia rozkaz Bora-Komorowskiego nakazał oddziałom z okolic Warszawy ruszyć na pomoc stolicy. 
wyjściem. W „oddolnych” relacjach wojennych z przedmieść Warszawy mamy jednak do czynienia $\mathrm{z}$ inną sytuacją: metaforyczne obrazy stolicy nie były budowane na potrzeby propagandy. Autorzy tekstów używali ich, aby opisać doświadczenia, dla których nie znajdowali innych środków wyrazu.

Najczęstszą metaforą, w prawie każdej narracji, jest obraz Warszawy jako dymiącego wulkanu. Chociaż sam wyraz „wulkan” pojawia się w relacjach bardzo rzadko (jeśli już, to w utartych zwrotach typu „siedzieliśmy jak na wulkanie”), często przywoływany jest obraz odległych łun i słupów dymu. Henryk Krzyczkowski pisze o Pruszkowie zasypywanym niczym Pompeje popiołem przenoszonym z Warszawy, w której paliło się getto: „Wiatr przenosił do Pruszkowa nadpalone kawałki papieru - spopielone szczątki książek i przejmujący zapach spalenizny. Znów Warszawę spowijały dymy, a w nocy niebo jaśniało wielkimi łunami” (Krzyczkowski 1986: 110). Podobny obraz odnajdujemy we wspomnieniach Tadeusza Jakubowskiego: „Któregoś dnia w kwietniu 1943 roku siostra moja Wiesia zauważyła na rzodkiewkach, botwinie i flancach sałaty czarne, spalone, niewielkie kawałki papieru. Gdy spojrzałem w górę, zobaczyłem takie same skrawki papieru lecące z wiatrem z Warszawy. Nie wiedzieliśmy dlaczego tak się dzieje”. Okazało się, że „w czasie tych pożarów nad gettem powstawał ogromny słup gorącego powietrza, który posuwał się ku górze, jakby zasysał palące się papiery windowane bardzo wysoko. [...] Wiatry w kierunku Pruszkowa przywiewały te skrawki spalonego papieru nad nasz ogródek, odległy od getta o przeszło $17 \mathrm{~km}$. Musiały to być olbrzymie pożary. Wieczorem zza naszego domu widać było czerwoną łunę nad Warszawą" (Jakubowski 2014: 133-134). W powieści $W$ matni, opowiadającej o okupacyjnych realiach okolic Grodziska Mazowieckiego, autorka również przywołuje obraz widocznych z oddali łun ognia, tym razem jednak obraz dotyczy powstania warszawskiego: „Niebo nad Warszawą stawało się coraz bardziej krwawe, a dym widoczny był z odległości trzydziestu kilometrów. Łuna zajmowała szeroki pas nieba ponad konarami wysokich drzew rosnących niedaleko domu Baśki i Janki” (Wiśniewska 2010: 237). Obraz widocznych $\mathrm{z}$ daleka łun pożarów i dymu powraca $\mathrm{w}$ wielu relacjach $\mathrm{i}$ wiąże się zawsze z poczuciem niebezpieczeństwa, co prawda odległego, ale jednak zagrażającego nawet pozornie spokojnym podmiejskim okolicom.

Drugim obrazem, niezbyt częstym, ale za to powracającym w dyskusji publicznej aż do dzisiaj, jest wizualizowanie Warszawy i okolic jako pustego w środku okręgu. Obwód Powiat Warszawski Armii Krajowej nosił nazwę Obroża, z kolei w różnych relacjach okolice warszawskie bywają nazywane „obwarzankiem” (por. Obroża 2015). W przedstawieniach wizualnych podwarszawska „obroża” jest ukazywana jako pusty okrąg, przez którego środek przechodzi duży, dominujący znak Polski Walczącej (por. np. Włochy w cieniu... 2004: 62). Okrąg czy też „obwarzanek” jest oczywiście nawiązaniem do kształtu powiatu warszawskiego, który obejmował pierścień podwarszawskich miejscowości, podczas gdy Warszawa była miastem wydzielonym, funkcjonującym na zasadach powiatu grodzkiego (Załęczny 2015: 9). Obwód Powiat Warszawski AK działał od 1940 roku, dzielił się na dziewięć regionów 
i obejmował cały teren powiatu. Służyło w nim prawie 16 tys. osób, dowództwo zaś mieściło się w Warszawie. W skład „Obroży” wchodziły więc obszary odległe od siebie, leżące w rejonach różniących się warunkami topograficznymi, co uniemożliwiało wspólne skoordynowane działania. Jak pokazały wydarzenia związane z godziną „W”, szwankowała też łączność tych rejonów z centrum. W tym kontekście metafora pustego okręgu nabiera dodatkowego sensu: ukazuje stolicę jako próżnię wysysającą ludzi i zasoby z otaczających terenów, pochłaniającą wszystko, co znajdzie się w jej pobliżu i wyrzucającą z siebie tylko chmury dymu oraz tłumy zabitych i rannych. Pustka w środku „obroży” może też kojarzyć się z miejscem, które — chociaż powinno być punktem dowodzenia - milczy, nie odpowiada na pytania, nie słyszy głosów z obrzeży.

Trzecim metaforycznym często powracającym obrazem jest przedstawianie centrum - Warszawy - jako czegoś, co rzuca cień na okoliczne miejscowości. Metafora ta znalazła się w tytułach dwóch książek poświęconych przebiegowi wojny w okolicach podwarszawskich: W cieniu Warszawy (Krzyczkowski 1986), opowiadającej o Pruszkowie i Włochy w cieniu powstańczej Warszawy (2004). Nawiązania do tego obrazu znajdują się również w wielu relacjach i opracowaniach dotyczących przebiegu powstania w podwarszawskich miejscowościach (także na prawym brzegu Wisły), w których autorzy często nadmieniają, że lokalna historia została przyćmiona czy też zmarginalizowana przez wydarzenia w Warszawie. Dostrzega to także Jolanta Załęczny, stwierdzając, że powiat warszawski jako jedyny spośród powiatów województwa warszawskiego do roku 2015 nie doczekał się swojej monografii, ponieważ zbyt mocno był związany z dominującym centrum, którym była Warszawa (Załęczny 2015: 8). Autorzy publikacji, takich jak Włochy w cieniu powstańczej Warszawy starają się podkreślić przede wszystkim, że mieszkańcy tej dzielnicy brali udział w powstaniu we „właściwej” Warszawie - na Żoliborzu, Mokotowie czy Starym Mieście. Chociaż opisują lokalną działalność, taką jak organizowanie zaopatrzenia, kolportaż prasy, a w późniejszym okresie zapewnienie schronienia tysiącom uchodźców, aktywność taka jest uznawana za mniejszy powód do dumy niż udział w wydarzeniach w centrum. Świadczy o tym chociażby omawiana już polityka tworzenia miejsc pamięci w przestrzeni miasta, lecz także język używany w narracjach. Publikacja, która ma przedstawić życie dzielnicy Włochy w okresie powstania warszawskiego, prezentuje, jak zapowiedziano w przedmowie, „udział różnych grup wojskowych oraz ludności cywilnej Okęcia i Włoch w walkach z okupantem i pomoc niesioną powstańcom" (Włochy w cieniu... 2004: 5). Chociaż z pewnością nie taka była intencja autorki przedmowy, użyte tam sformułowania mogą sugerować, że życie ludności przedmieść jest ważne tylko o tyle, o ile może przynieść pożytek centrum. To, co jest lokalne i nie wiąże się bezpośrednio z nurtem wielkiej historii, ginie w cieniu. 


\section{Podsumowanie: brak podmiejskiej „ikony”}

Ważne wydarzenia historyczne - jak druga wojna światowa w Polsce albo też powstanie warszawskie - są często $\mathrm{w}$ dyskursie popularnym sprowadzane do kilku obrazów: żołnierze niemieccy wyważający szlaban na Westerplatte, wieża płonącego Zamku Królewskiego, mały powstaniec w za dużym hełmie, barykada z przewróconego tramwaju. Jak zauważa Cornelia Brink (2000: 136), takie obrazy („ikony”), powielane $\mathrm{w}$ nieskończoność $\mathrm{w}$ różnych środkach przekazu, pełnią funkcję bardzo mocno oddziaływujących metafor. Nadają przedstawianym zdarzeniom sens moralny, etyczny i symboliczny. Na zasadzie metonimii traktuje się je jako przedstawienia całych długotrwałych i złożonych procesów (obraz małego powstańca "streszcza" całe powstanie warszawskie). Fotografie te bywają nawet używane, aby przedstawić abstrakcyjne wartości lub pojęcia, takie jak honor, godność, wina, niesprawiedliwość (por. Brink 2000: 136).Tego typu klisze upraszczają i stereotypizują obraz wojny, ale jednocześnie sprawiają, że jest on obecny w pamięci odbiorców. Tworzą pewien model, ramy, do których mogą się odnieść kolejni narratorzy, przyjmując je bądź odrzucając. Narracje wojenne dotyczące okolic podwarszawskich nie doczekały się takich czytelnych i obecnych w świadomości odbiorców ikon. Nie można wskazać zdjęcia, obrazu, wiersza czy piosenki, a nawet budynku czy miejsca, które jednoznacznie kojarzyłyby się z wojną w okolicach podmiejskich i w sposób symboliczny wyrażały jej specyfikę. Sprawia to, że obraz wojny w miejscowościach podwarszawskich często nawet $\mathrm{w}$ pamięci ich mieszkańców zostaje przyćmiony przez tragedię Warszawy. Wojna na przedmieściach staje się „nieopowiadalna”, ponieważ nie ma ram, w które można wpisać tego typu narracje - można tylko przykrawać je i dopasowywać do schematów opowieści funkcjonujących w obiegu narodowym. Z drugiej strony, brak jednej, czytelnej metafory, ikony streszczającej w sobie koleje wojny na przedmieściach sprawia, że historia ta nadal pozostaje otwarta na różne sposoby opowiadania i różne interpretacje.

\section{Bibliografia}

Brink C. (2000): Looking at photographs from Nazi concentration camps, „History \& Memory” 12, nr 1, s. $135-150$.

Cabanowski M. (1996): Bombardowanie na akord, [w:] idem, Mój Grodzisk, Warszawa.

Centra - peryferie w literaturze polskiej XX i XXI wieku (2015): red. W. Browarny, E. Rybicka, D. Lisak-Gębala, Kraków.

Chmielarz W. (2017): Lekceważenie obwarzanka, „Laboratorium Więzi” 8.02.2017, http://laboratorium.wiez.pl/2017/02/08/lekcewazenie-obwarzanka/ (dostęp: 12.05.2017).

Duszak A. (2012): Centra, hybrydy i zmiana społeczno-dyskursywna, „Oblicza Komunikacji” 5, s. 9-24.

Foss S. (2009): Rhetorical Criticism. Exploration and Practice, Long Grove.

Gawkowski R. (2012): Tablice pamięci. Miejsca pamięci narodowej w dzielnicy Włochy, Warszawa.

Gmurski J. (2007): Zarys dziejów Kuklówki XV-XX wiek, Warszawa. 
Gozdawa-Gołębiowski J. (1992): Obszar Warszawski Armii Krajowej, Lublin.

Halaba R. (1961): Z dziejów walk z reakcyjnym podziemiem w woj. warszawskim w latach 1945-1947, „Notatki Płockie” 6, nr 20, s. 14-17.

Hładowska A. (2014): Dziennik osobisty z lat 1939-1945, [w:] Milanówek: pamięć i fascynacja, red. A. Pettyn, Milanówek, s. 321-346.

Jakubowski T.H. (2014): Lata prawie bezgrzeszne, Pruszków.

Krzyczkowski H. (1986): W cieniu Warszawy. Pruszków w latach okupacji hitlerowskiej, Warszawa.

Miejsca Pamięci! Walka i Konspiracja!, http://miejscapamiecigrodzisk.pl/mapa/miejscapamieci/ (dostęp: 12.05.2017).

Mikołajczak M. (2015): Między mimikra a rebelią. Pejzaż (post)kolonialny regionalnej literatury, [w:] Centra - peryferie w literaturze polskiej XX i XXI wieku, red. W. Browarny, E. Rybicka, D. Lisak-Gębala, Kraków, s. 30-50.

Niemieccy bandyci powietrzni walczq z ludnością cywilna (1939): „Goniec Warszawski” 5, nr 247, s. 5.

Obroża. VII obwód okręgu AK Warszawa Miasto (2015), http://www.sppw1944.org/pamiec/obroza_1. pdf (dostęp: 12.05.2017).

Okupacyjny Pruszków, http://poznaj.pruszkow.pl/trasy/okupacyjny-pruszkow/ (dostęp: 1.05.2017). Rumianek S. (2008): Szpitale wojenne w Brwinowie 1944-1945, „Brwinowskie Zeszyty Historyczne” 1. Rybicka E. (2015): Relacje centro-peryferyjne a polityka konstruowania tożsamości regionalnej, [w:] Centra - peryferie w literaturze polskiej XX i XXI wieku, red. W. Browarny, E. Rybicka, D. Lisak-Gębala, Kraków, s. 13-29.

Specjalne pociagi dla pragnących opuścić stolicę (1939): „Goniec Warszawski” 5, nr 244, s. 6.

Szurek A. (2015), Ujawnić, upamiętnić, zrozumieć — zapomnieć? Narracje o bombardowaniu Grodziska Mazowieckiego w styczniu 1945 roku — próba analizy retorycznej, [w:] Literatura i kultura popularna. Badania, analizy, interpretacje, red. A. Gemra, Wrocław, s. 138-153.

Szurek A. (2016): Obraz podwarszawskich letnisk w prasie dwudziestolecia międzywojennego, „Kultura Popularna" 1 (47), s. 74-87.

Wiśniewska A.B. (2010): W matni, Kozerki.

Włochy w cieniu powstańczej Warszawy (2004): red. W. Wysocki et al., Pruszków-Warszawa.

Woźnicka J. (2013): Z pamiętnika panny Ady, [w:] W pamięci zapisane. Grodzisk Mazowiecki. Wspomnienia różne, zebr. i oprac. A. Szafrańska, Grodzisk Mazowiecki 2013.

Zalewski W. (npubl. mpis): Wspomnienia rodzinne.

Załęczny J. (2015): Powiat warszawski w czasach II Rzeczypospolitej, Warszawa.

Skarby wojenne w workach wieśniaczych (1939): „Express Poranny” nr 260, s. 2.

\section{Centre-periphery relations in 'grassroot' war narratives from Warsaw suburban region}

\section{Summary}

This paper explores the relations between the centre and the peripheries drawing on examples from war narratives and accounts from Warsaw suburban region. Narratives analyzed here belong all to 'grassroot' history (private diaries, monographies by non-professional historians, books published by small, local editorial presses, websites run by local institutions, visual symbols in towns' space). Main problems addressed in the article are: are the centre and the suburbs described as binary oppositions or rather in terms of gradation? Do the narrators use the strategy of 'mimicry' or rather the one of 'rebellion' towards the centre? The paper concludes with pointing out three metaphors, which provide patterns to the centre-periphery relations in analyzed region: Warsaw as a volcano, as an empty circle and as a mountain or tower casting a long shadow.

Keywords: Warsaw, Warsaw Uprising, suburbs, metaphor.

Oblicza Komunikacji 8, 2015

(C) for this edition by CNS 